\title{
麻痺性貝毒のマウス試験におけるカルシウムの影響*1
}

(平成 3 年 2 月 28 日受理)

$\begin{array}{ll}\text { 只野敬子安安田和男*2 } \\ \text { 牛山博文 } & \text { 二島太一郎 }\end{array}$

\section{Effect of Calcium on the Mouse Bioassay Method for Paralytic Shellfish Poison (Hygienic Studies on Health Food (III))}

\author{
Keiko Tadano*2, Kazuo Yasuda ${ }^{* 2}$, Hirofumi Ushiy ama*2 and Taichiro Nishima ${ }^{* 2}$ \\ ${ }^{(* 2}$ The Tokyo Metropolitan Research Laboratory of Public Health: 3-24-1, \\ Hyakunin-cho, Shinjuku-ku, Tokyo, Japan)
}

\begin{abstract}
Seventeen oyster extract tablets, so-called health food, on the market were investigated for paralytic shellfish poison (PSP) by the standard mouse bioassay method. Eleven samples contained toxicity in the range of 3.9-12.5 MU/g. However, in samples that had a positive mouse bioassay result, PSP was not identified by thin-layer chromatography and fluorescence analysis and was also not detected by high performance liquid chromatography.

It was found that the mouse toxicity was correlated with the concentration of calcium in samples. The toxicity may be caused by the conversion of $\mathrm{CaCO}_{3}$ in tablets into $\mathrm{CaCl}_{2}$ by $\mathrm{HCl}$ used for the extraction of PSP. It was found that sulfuric acid, citric acid or phosphoric acid could be employed to extract PSP in place of $\mathrm{HCl}$.
\end{abstract}

(Received February 28, 1991)

Key words：健康食品 health food；麻痺性貝毒 paralytic shellfish poison；カキ oyster；カキエ キス錠剂 oyster extract tablet; マウス試験法 mouse bioassay method; マウス mouse; 炭酸 カルシウム calcium carbonate; 塩化カルシウム calcium chloride

\section{緒言}

著者らは，健康食品として市販されている多種多様の 食品について, 安全性評価を目的として従来から種々の 衛生学的調查を行(報告), 2) してきた。今回は, 海産物を 主原料とする健康食品のうち, 需要の多い貝類を原料と する製品について調查した。

貝類については, 二枚貝が有毒プランクトンの渦鞭毛 藻 Alexandrium 属を摄取して消化管 (中腸腺)などに蓄 積することにより, 貝が毒化する麻痺性貝毒が知られて いる.

現在, 麻痺性貝毒としてサキシトキシン saxitoxin (STX) 群，ゴニオトキシン gonyautoxin (GTX) 群など 十数種の毒素が確認されている. 近年, 毒化する貝の種 類も増加し, 貝毒発生地域む全国的に拡大する傾向が認 められている゙3.

\footnotetext{
*1 健康食品の衛生学的調查（第 3 報）

*2 東京都立衛生研究所：東京都新宿区百人町 3-24-1
}

そこで，貝類製品のうち過去にいくつか中毒事例報 告4).5)がある力キを主原料とするカキ加工食品の力キエ キス錠剂について, 麻痺性貝毒試験を行った。

麻渒性貝毒試験法としては，A. O. A. C. 法6)に基づい たマウスを用いる動物試験のみが公定法7として定めら れている. そこでこの公定法》に従って試験を行ったと ころ, マウスが麻痺性貝毒によると見られる症状を呈し て死亡する例があった。しかし，化学試験により麻痺性 貝毒の確認を行ったが貝毒は検出されなかったため，そ の致死原因を検討した結果, 若干の知見が得られたので 報告する.

\section{実験方法}

1. 試料

試料は, 都内のデパート及び健康食品専門店で市販さ れていたカキェキス錠剤 17 試料（8社）を用いた.

\section{2. 貝毒標準品, 毒化貝抽出液及び毒化貝}

1）貝毒標準品及び毒化ホタテガイ抽出液 STX 群 (STX, neoSTX) 標準品, GTX 群 $\left(\mathrm{GTX}_{1}\right.$, 
$\left.\mathrm{GTX}_{2}, \mathrm{GTX}_{3}, \mathrm{GTX}_{4}\right)$ 標準品及び毒化ホタテガイ酢酸抽 出液は東京大学農学部水産化学教室より分与されたもの である.なお，ホ夕テガイ抽出液のマウス毒性は 66 $\mathrm{MU} / \mathrm{ml}$ であった.

2) 毒化アカザラガイ抽出液

毒化アカザラガイ酢酸抽出液は宮城県気仙沼保健所よ り分与されたあのである。なお，アカザラガイ抽出液の マウス毒性は $8.6 \mathrm{MU} / \mathrm{ml}$ であった.

3) 毒化ホタテガイ

毒化ホタテガイ 20 個は 1990 年 5 月に岩手県大船渡 湾で採取され，岩手県水産試験場より分与されたもので ある.

それらの中腸腺を摘出して合し，ホモジナイザーで磨 砕均質化した後, 約 $20 \mathrm{~g}$ づつ共栓試験管に分取し, 凍結 保存した。なお，この中腸腺のマウス毒性は $124 \mathrm{MU} / \mathrm{g}$ であった。

\section{3. 試薬及び装置}

1) カラムクロマトグラフィー用活性炭：和光純薬工 業(株)製

2) 薄層用シリカゲルプレート：DC-Fertigplatten kieselgel 60, Merck 社製

3) その他の試薬はいずれも市販特級品を用いた.

4）高速液体クロマトグラフ：(株) 日立製作所製, 638-50 型（けい光検出器付）

5）けい光分光光度計：(株) 日立製作所製, MPF-4 型

6) 原子吸光光度計：Varian 社製，AA-975 型

4. 動物試験

食品衛生検查指針 II, 麻痺性貝毒試験法 ${ }^{77}$ に従い次の とおり行った。

\section{1 試験溶液の調製}

粉砕した試料 $10 \mathrm{~g}$ を科り， $0.1 \mathrm{~N}$ 塩酸 $30 \mathrm{ml}$ を加え てかくはんし， $5 N$ 塩酸で $\mathrm{pH} 3$ に調整した後, 沸騰水 浴中 5 分間加温した。室温まで放冷後, 再び pH3 に調 整した後, 水で $40 \mathrm{ml}$ とし, よくかくはんしてから $3,000 \mathrm{rpm}$ で 5 分間遠心分離を行い, 上澄液を試験溶液 とした.

\section{2 マウス試験方法}

4 週歯の ddY 系雄マウスを購入し, 3 日間予備飼育 後, 体重 19〜21 g のあのを選び 1 群 5 匹としてマウス 試験を行った。試験溶液 $1 \mathrm{ml}$ を腹腔内投与し，マウス が麻痺性貝毒による典型的な症状を呈し死亡するまでの 時間から，中央致死時間を求め, Sommer の表吕により マウス単位 $(\mathrm{MU})$ に換算した。 この時の $1 \mathrm{MU}$ とは体重 $20 \mathrm{~g}$ のマゥスを 15 分で死亡させる毒量を言う.さら に, 得られたマウス単位を, 試験溶液中の試料量で除し た值を試料 $1 \mathrm{~g}$ 当りの毒力として, $\mathrm{MU} / \mathrm{g}$ で表わした.

\section{5. 化学試験}

\section{1 試験溶液の調製8)}

マウス試験で用いた試験溶液 $3 \mathrm{ml}$ を, さらに $1 \mathrm{~N}$ 水
酸化ナトリウムで pH 5.5 に調整し，活性炭カラムに負 荷した。蒸留水約 $20 \mathrm{ml}$ で十分洗浄した後，酢酸-20\% エタノール $(1: 99)$ 混液 $15 \mathrm{ml}$ で溶出した。溶出液を減 圧濃縮し，水で $3 \mathrm{ml}$ としたものを試験溶液とした。

\section{2 試験方法}

1) 薄層クロマトグラフィー9)（TLC 法）

試験溶液 $20 \mu \mathrm{l}$ をシリカゲルプレートに塗布し，1-ブ タノールー酢酸ー水 $(2: 1: 1)$ 混液を用いて展開した。プ レートを風乾後， $1 \%$ 過酸化水素水を噴霧し $110^{\circ}$ で 5 分間加熱した．放冷後，紫外線 $(365 \mathrm{~nm})$ 照射下で試料 のけい光を観察し，同様に操作した毒化貝のけい光スポ ットのRf 值及び色調と比較して判定した。

2) けい光強度法

麻痺性貝毒の多くはアルカリ性下で過酸化水素処理を 行うと, けい光物質に変換する ${ }^{10)}$.

そこで, 試験溶液 $1 \mathrm{ml}$ に $0.5 \mathrm{~N}$ 水酸化ナトリウム 1 $\mathrm{ml}$ 及び $4 \%$ 過酸化水素水 $0.3 \mathrm{ml}$ を加え, 暗所で 30 分 間放置後, 酢酸を加えけい光強度 (励起波長 $340 \mathrm{~nm}$, け い光波長 $395 \mathrm{~nm}$ ） を測定し，同様に操作した毒化貝抽 出物と比較した。

3） 高速液体クロマトグラフィー（HPLC 法）

長島らの方法 ${ }^{11)} に$ 従い, 過ヨウ素酸酸化によるポス卜 カラム法で測定した.

\section{6. 無機成分の測定}

衛生試験法・注解 ${ }^{12)}$ に従い, カルシウム, カリウム, 七素は原子吸光法, ホウ素はクルクミン発色法, 塩化ナ トリウムはモール法により測定した。

\section{実験結果及び考察}

\section{1. 動物試験}

市販のカキエキス錠剤 17 試料を公定法 ${ }^{7)}$ に従って調 查したところ，11 試料から 3.9 12.5 MU/g のマウス 毒性が認められた。

そこで，このマウス毒性を食品衛生法 ${ }^{13)}$ 及び健康食品 業界の自主規格基準 ${ }^{14)}$ に照らし合せ考察した。食品衛生

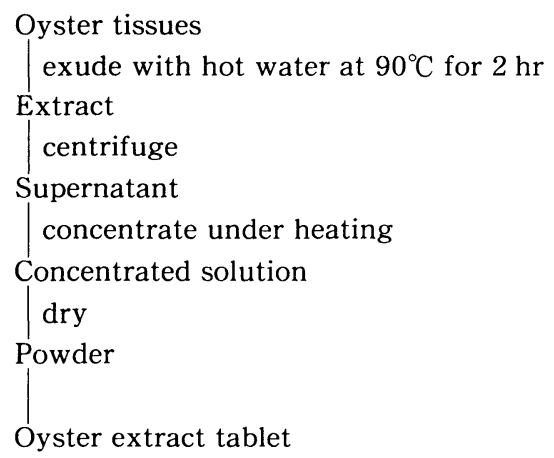

Fig. 1. Manufacturing process for oyster extract tablet 


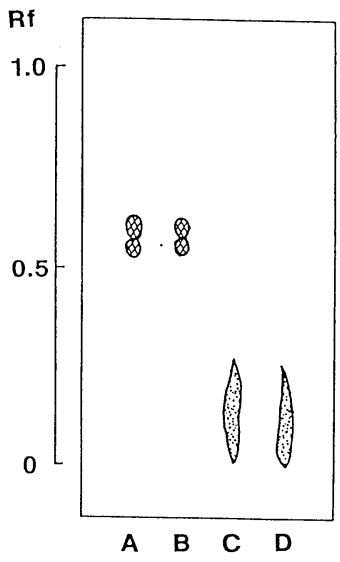

Fig. 2. Thin-layer chromatogram of extract of oyster extract tablets

A: extract of toxic scallop Patinopecten yessoensis

B: extract of toxic scallop Chlamys nipponensis akazara

C: extract of oyster extract tablet (I)

D: extract of oyster extract tablet (II)

TLC plate: kieselgel 60

Developing solvent: 1-butanol-acetic acidwater $(2: 1: 1)$

After development, the plate was air-dried, sprayed with $1 \% \mathrm{H}_{2} \mathrm{O}_{2}$, and heated at $110^{\circ} \mathrm{C}$ for $10 \mathrm{~min}$, and fluorescent spots were detected under UV light at $365 \mathrm{~nm}$.

(blue fluorescence; 9 : white fluorescence

法 $^{13)}$ においては貝類のむき身の暫定的出荷規制値は 4 $\mathrm{MU} / \mathrm{ml}$ と定められているのみで, カキ加工食品につい ての基準値はないため, 直ちに不適品とは言えない。し かし, 自主規格基準 ${ }^{14)}$ ではカキ加工食品は「カキの水抽 出物の乾燥重量が製品の $40 \%$ 以上含有するあの」之定 義された上で, 貝毒については「検出されてはならない」 と定められていることから考えると， マウス毒性が認め られた試料は不適品とみなされる。

次に, Fig. 1 に示したカキエキス錠剤の製造工程の一 例から，これらのマウス毒性が認められた原因を考察し た。この製造法から考えると麻痺性貝毒は水溶性のため 溶出されやすく，また，熱に対してあ安定であるため, エキス分を抽出するときの $90^{\circ}$ 程度の温度では分解され にくいものと思われる，さらに，製造過程には濃縮工程 があるため, 原料のカキが低毒力の場合でも製品では高 濃度になることも考えられる。

\section{2. 化学試験}

動物試験でマウス毒性を示した試料について，TLC 法, けい光強度法及び HPLC 法により化学試験を行い 貝毒の確認及び毒成分の同定を試みた。

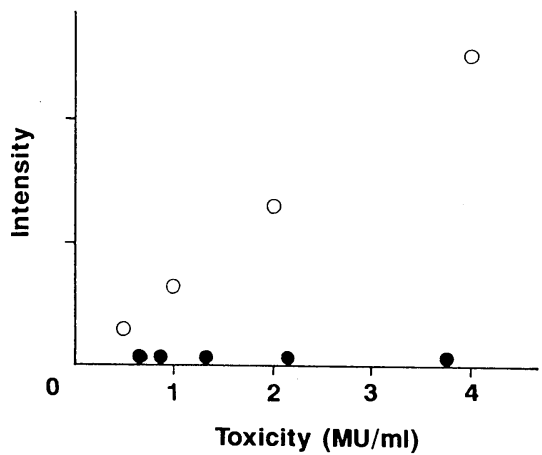

Fig. 3. Relationship between the toxicity and fluorescence intensity in standard and sample extracts

Fluorescent monitor: Ex. 340 nm; Em. 395 $\mathrm{nm}$

$\bigcirc$ : extract of toxic scallop Patinopecten yessoensis; 0 : extract of oyster extract tablet

1) TLC 法

カキエキス錠剂抽出物の薄層クロマトグラムを Fig. 2 に示した．毒化ホタテガイ及びアカザラガイ抽出物に は, $R f 0.6$ 付近に麻痺性貝毒によると思われる 2 つの青 白いけい光が認められた。 しかし, 試験溶液ではマウス 試験で陽性を示したにもかかわらず，同様の $R f$ 值付近 にけい光スポットは見られなかった。

2)けい光強度法

マウス毒性とけい光強度の関係を Fig. 3 に示した. 毒 化ホタテガイから調製した 0.5 4 MU/ml の溶液では, マウス毒性が強くなるに従いけい光強度はほぼ比例して 增加した。しかし，試験溶液については，それぞれのマ ウス毒性を示す $\mathrm{MU} / \mathrm{ml}$ 值に対応したけい光強度の増 加は認められなかった。

3) HPLC 法

TLC 法及びけい光強度法では酸化剂として過酸化水 素を使用するため， GTX 窒素に水酸基を持つ成分はけい光を発しない，そこで， 特異性と検出感度を高めるため過ヨウ素酸で酸化後, 塩 化アセトアルデヒドと反応させるポストカラム方式によ る HPLC 法 ${ }^{11}$ を用いた。 貝毒標準品（STX 群混合標準 溶液： $0.1 \mathrm{MU} / \mathrm{ml}$, GTX 群混合標準溶液： $0.2 \mathrm{MU} / \mathrm{ml}$ ) 及びカキエキス錠剤抽出物（試験溶液： $0.5 \mathrm{MU} / \mathrm{ml}$, 錠 剂あたり：12.0 MU/g）のクロマトグラムをFig. 4 に示 した。 マウス試験で陽性を示した試料でもSTX 群, GTX 群に相当する位置にピークは見られなかった。

以上のことから， マウス試験で毒性を示す試料であっ ても, 3 通りの化学試験で貝毒が検出されないという矛 盾した結果が得られた。

\section{3. マウス致死原因の検討}

動物試験ではマウスが麻㾇性貝毒と酷似した症状を呈 

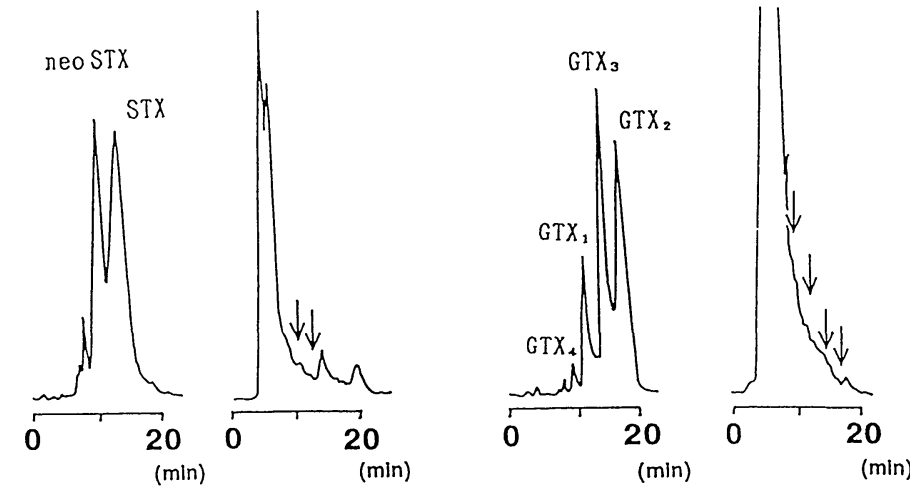

$$
\begin{aligned}
& \text { STXs } \\
& \\
& \quad \text { oyster extract tablet }
\end{aligned}
$$

G T X S

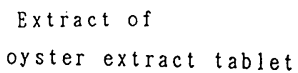

Fig. 4. High performance liquid chromatograms of extract of oyster extract tablet and standards HPLC conditions ${ }^{11)}$

Column: silica ODS column $(6 \mathrm{~mm}$ i.d. $\times 300 \mathrm{~mm})$; mobile Phase: $2 \mathrm{~m} M$ heptanesulfonic acid in $0.05 M$ phosphate buffer (pH 7.0) - methanol (STXs. $75: 25$; GTXs. 99 : 1); flow rate: $1.0 \mathrm{ml} / \mathrm{min}$

Reagents for detection of toxin: (I) $0.05 M$ periodic acid; (II) $0.2 N \mathrm{KOH}$ plus $1 M$ ammonium formate in $50 \%$ formamide; (III) $1 \%$ chloroacetaldehyde in $1 M$ citrate buffer $(\mathrm{pH} 4.0)$

Fluorescent monitor: Ex. 336 nm; Em. 390 nm

し死亡したにあかかわらず，化学試験では麻痺性貝毒が 検出されなかった.これは貝毒以外の要因がマウス致死 に影響を及ぼしたものと考え，力キエキス錠阂中の成分 について検討を行った。

\section{1) 錠斉中成分の調查}

カキエキス錠剂は, カキエキスパウダーに乳糖，デン プンなどを加え成形した後, 炭酸カルシウム, 白糖など でコーティングしたものである.

そこで, これら白糖, 色素, 結晶セルロース及び炭酸 カルシウムなどの各原料の他, 塩分濃度及び各種元素な どがマウス毒性を示すか否かについて調查した。

各原料のそれぞれについて，マウス試験溶液中におけ る濃度に相当する量を公定法による試験操作に従いマウ スに投与したところ，炭酸カルシウムの場合のみ麻痺性 貝毒と酷似した症状を呈しマウスが死亡した。 しかし， 炭酸カルシウムは不溶性であり，そのまま水に䁖濁させ マウスに投与した場合は毒性を現さなかった。

このことから， 公定法 ${ }^{7} に$ 従うとマウスが死亡した原 因は，抽出及び $\mathrm{pH}$ 調整の際に使用する塩酸により炭酸 カルシウムが解離して可溶性の塩化カルシウムとなり, それが毒性を示すものと推察した。

そこで, カキエキス錠剤抽出物の MU 值とカルシウム 濃度の関係を検討したところ，Table 1 に示すように MU 值の高い試料では明らかにカルシウム濃度も高い傾
Table 1. Mouse Toxicity and Calcium Content in Oyster Extract Tablets

\begin{tabular}{ccc}
\hline No. of samples & Toxicity $(\mathrm{MU} / \mathrm{g})$ & $\mathrm{Ca}(\mu \mathrm{g} / \mathrm{g})$ \\
\hline 1 & $\mathrm{ND}$ & 100 \\
2 & $\mathrm{ND}$ & 600 \\
3 & $\mathrm{ND}$ & 1,600 \\
4 & $\mathrm{ND}$ & 3,000 \\
5 & $\mathrm{ND}$ & 3,400 \\
6 & $\mathrm{ND}$ & 4,000 \\
7 & 3.9 & 11,000 \\
8 & 4.3 & 7,900 \\
9 & 4.9 & 18,800 \\
10 & 5.5 & 6,800 \\
11 & 5.7 & 7,500 \\
12 & 6.5 & 7,700 \\
13 & 6.8 & 7,600 \\
14 & 7.2 & 25,900 \\
15 & 11.8 & 35,000 \\
16 & 12.0 & 41,000 \\
17 & 12.5 & 43,000 \\
\hline
\end{tabular}

ND: not detected $(<3.5 \mathrm{MU} / \mathrm{g})$

向が認められた。

なお，確認のためカキエキス錠㶡のコーティング部分 の炭酸カルシウム層を剝離して除き，マウス試験をした 


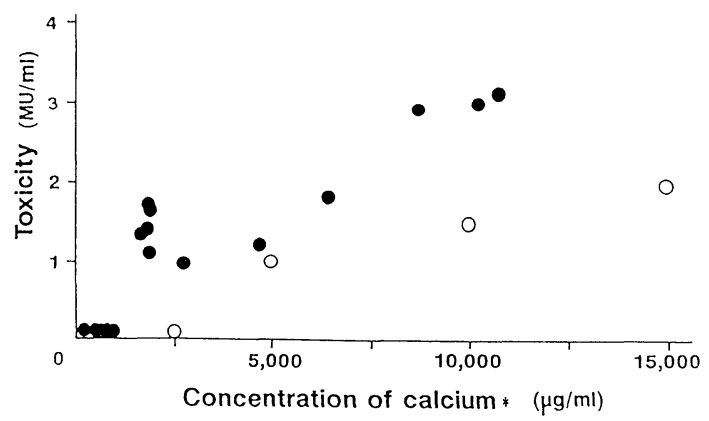

Fig. 5. Relationship between the toxicity and the concentration of calcium in extract of oyster extract tablets and calcium chloride solution

$\bigcirc$ : calcium chloride solution; 0 : extract of oyster tablet

* Concentration in mouse test solution

ところ，いずれの試料もマウスの死亡を認めなかった.

一方, 壏化ナトリウムの濃度が 3〜4\% 以上になると マウスに影響を与える ${ }^{15)}$ と言われるが，試料の試験溶液 中の濃度は $0.25 \sim 2.1 \%$ であるので，マウス致死に特に 影響はないものと考える。実際，塩化ナトリウム濃度 $5 \%$ で同様に試験した場合でもマウスが死亡することは なかった.

錠風成分のうち，濃度によってはマウス致死に影響を 及ぼすと考えられる各種元素について試験溶液中の濃度 を测定した. 七素は $\operatorname{Tr} \sim 0.8 \mu \mathrm{g} / \mathrm{ml}$ ， カリウムは 1,300 $\sim 4,000 \mu \mathrm{g} / \mathrm{ml}$ 及びホウ素は $\mathrm{Tr} \sim 0.6 \mu \mathrm{g} / \mathrm{ml}$ でいずれ あマウスの致死原因となるような濃度ではなかった。 ま た,これらの含有量と各試料の MU 值との相関も認めら れなかった。

2) 塩化カルシウムのマウス毒性

マウスの死亡原因と推察された塩化カルシウムのマウ ス毒性を確認するために, 塩化カルシウム標準溶液をマ ウス腹腔内に投与したところ，マウスは死亡し，その症 状は貝毒による症状に酷似していた。 カキェキス錠剤よ り得られた試験溶液中のカルシウム濃度及び塩化カルシ ウム標準溶液におけるカルシウム濃度とマウス毒性との 関係を Fig. 5 に示した.

試料より得られた試験溶液の場合はカルシウム濃度 $2,000 \mu \mathrm{g} / \mathrm{ml}$ 以上で，塩化カルシウム標準溶液の場合は $5,000 \mu \mathrm{g} / \mathrm{ml}$ 以上でカルシゥム濃度と MU 值の間に明 らかに正相関が認められた。

カルシウムイオンは生体内において細胞膜の透過性, 神経, 心臓, 筋などの興奮性, 血液凝固, ある種の酵素 の活性化などの生命現象の維持に重要な役割を持ってい

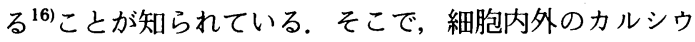
ムイオンの一定濃度差を維持することは細胞にとって必 須である ${ }^{17)}$. したがって, 高濃度の塩化カルシウムがマ
Table 2. Comparison of Extract Rate with Various Acids

\begin{tabular}{lcc}
\hline \hline $\begin{array}{c}\text { Solvents for } \\
\text { extraction }\end{array}$ & $\begin{array}{c}\text { Toxicity } \\
(\mathrm{MU} / \mathrm{g})^{*}\end{array}$ & $\begin{array}{c}\text { Relative } \\
\text { toxicity** }\end{array}$ \\
\hline Hydrochloric acid & 124 & 1.0 \\
Sulfuric acid & 137 & 1.10 \\
Citric acid solution & 134 & 1.08 \\
Phosphoric acid & 112 & 0.90 \\
Water & 104 & 0.83 \\
\hline
\end{tabular}

* Toxicity detected in degestive gland of toxic scallop Patinopecten yessoensis.

Each value is an avarage of 3 trials.

** Relative toxicity was expressed as a ratio of the toxicity of the extracts extracted with the solvents other than hydrochloric acid to the toxicity of hydrochloric acid extract.

ウス毒性に関与することは十分考えられる.

なお, カルシウム濃度が同程度でも塩化カルシウム標 準溶液に比較すると試験溶液の MU 值は若干高くなる 傾向が認められた. この原因としては, カルシウムの作 用の他に試験溶液中に存在する種々の塩類など, 個々に はマウスに対しほとんど作用を与えない無機成分の影響 が複合されて現われたことも考えられる。

\section{4. 麻瘒性貝毒の抽出における酸類の検討}

1) 各種酸類によるマウス試験への影響

カキエキス錠剤の貝毒試験を公定法7)に従い行うと, 塩酸で可溶性カルシウム塩が生成しマウス毒性を現わす ことが認められたので, 塩酸の代わりに他の酸類を抽出 溶媒として使用し, 炭酸カルシウムの影響を除くことが できるか否かを検討した。

硝酸, 硫酸, リン酸, 酢酸及び乳酸の各 $0.1 N$ 溶液及 びクエン酸の $0.1 M$ 溶液を用い, カキェキス錠剂につい て公定法 ${ }^{7)}$ 準じて試験溶液を調製しマウス試験を行っ た.

その結果, 塩酸の場合と同様に可溶性カルシウム塩が 生成されると思われる硝酸, 酢酸及び乳酸を用いた場合 はマウス毒性が認められ, 不溶性カルシウム塩が生成さ れると思われる硫酸, リン酸及びクエン酸溶液では毒性 が認められなかった。

なお, $0.1 N$ 硝酸, $0.1 N$ 酢酸及び $0.1 N$ 乳酸の各カル シウム塩標準溶液について，それぞれ 10,000 $\mu \mathrm{g}$ （カル シウムとして） $/ \mathrm{ml}$ 溶液 $1 \mathrm{ml}$ をマウスに腹腔内投与し たところ，いずれもマウス毒性のあることが確認され た.

2) 抽出率の比較

マウス試験でカルシウム塩の影響がなかった硫酸, リ ン酸及びクェン酸溶液について貝毒の抽出率を塩酸の場 合と比較した。 
凍結毒化ホタテガイ中腸腺試料を解凍し, 均一化した 後, $10 \mathrm{~g}$ づつを試験管に採取し， $0.1 \mathrm{~N}$ 塩酸， $0.1 \mathrm{~N}$ 硫 酸, $0.1 N$ リン酸及び $0.1 M$ クエン酸溶液各 $10 \mathrm{ml}$ を用 い,それぞれ公定法に準じ試験溶液を調製しマウス試験 を行った。

各酸類の抽出率を比較した結果を Table 2 に示した. 硫酸及びクェン酸溶液での抽出率は塩酸の場合に比較し て $10 \%$ 程度高く，リン酸では $10 \%$ 程度低い值だった。 しかし，マウスを用いた動物試験では $\pm 20 \%$ の定量誤 差を伴うものと見なされていることから，これらの酸の 抽出率は, 塩酸の場合と大差ないあのと考えられる. 一 方, 蒸留水 $(\mathrm{pH} \mathrm{6.0)}$ で抽出した場合は, いずれの酸と比 較しても抽出率は低かった。

この結果, 長島らの報告*3にああるように貝毒の抽出 には pH の影響が大きく, 抽出溶媒の酸の種類による差 はないため, 硫酸, クエン酸及びリン酸を用いても塩酸 を用いた場合と同程度に貝毒を抽出できることが分かっ た.

\section{まとめ}

健康食品として市販されているカキエキス錠剤 17 試 料について麻瘏性貝毒試験を行ったところ，11 試料か ら $3.9 \sim 12.5 \mathrm{MU} / \mathrm{g}$ のマウス毒性が認められた. しか し，この毒性を示した原因は，公定法7゙において抽出及び $\mathrm{pH}$ 調整に用いる塩酸が，錠剂のコーティング部分に使 用されている炭酸カルシウムを塩化カルシウムに変える ためであることが分かった。 さらに，この塩化カルシウ ムにより麻痺性貝毒と類似した症状を呈することを認め た.

そこで，本試料のように高濃度のカルシウムを含む製 品について, マウス試験でカルシウム塩の影響をうけな い酸類を検討したところ, 塩酸に代えて硫酸, クエン酸 及びリン酸などの酸を使用することができ，貝毒の抽出 も塩酸を使用した場合と同程度の結果が得られることが 認められた。

また，動物試験が公定法 性貝毒試験を健康食品のような加工製品に適用する場合 は, 含有成分に留意する必要があり, 特に多量のカルシ ウム塩を含有する試料については，公定法7)の塩酸の代 わりに硫酸, クエン酸及びリン酸を用いて試験溶液を調 製するか, HPLC 法などの他の分析手段を併用すること が必要と考える.
なお, 本研究の概要は日本食品衛生学会第 59 回学術 講演会（1990 年 5 月，東京）において発表した。

\section{謝辞}

本報告に際し, 御懇切なる御指導及び貴重な試料の御 提供をいただいた茨城大学橋本周久先生, 東京大学野口 玉雄先生, 浅川 学先生に深謝致します。

文献

1）安田和男, 西島基弘, 斎藤和夫, 上村 尚, 井部明広, 永 山敏廣, 牛山博文, 田端節子, 松本幸子, 直井家壽太, 二 島太一郎：食衛誌。 25, 371 377 (1984)

2）安田和男, 西島基弘, 斎藤和夫, 上村 尚, 井部明広, 永 山敏廣, 牛山博文, 田端節子, 直井家壽太, 二島太一郎： 同上 27, 302 310 (1986).

3) 安元 健: 化学と生物 27, 401 406 (1989).

4) Onoue, Y., Noguchi,T., Hashimoto, K.: Bull. Japan Soc. Sci. Fish. 46, 1,031 1,034 (1980).

5) 野口玉雄: 衛生化学 29, 10 15 (1983).

6) Horwitz, W., ed.: Official Methods of Analysis of A. O. A. C., 12 th Ed. p. 319 (1975), A. O. A. C., Washington, D. C.

7）厚生省環境衛生局 監修：“食品衛生検查指針 II” p. 240 ２44 (1978), 日本食品衛生協会.

8）菊地秀明, 牛沢 勇: 宮城県保健環境センター年報 2,104 $\sim 105$ (1984).

9) Shoptaugh, N. H., Buckley, L. J., Ikawa, M., Sasner, Jr., J. J.: Toxicon 16, 509 513 (1978).

10) Bates, H. A., Rapoport, H.: J. Agr. Food Chem. 23, 237 239 (1975)

11) Nagashima, Y., Maruyama, J., Noguchi, T., Hashimoto, K.: Nippon Suisan Gakkaishi 53, 819 823 (1987).

12) 日本薬学会編：“衛生試験法注解” p. 73 75, p. 270, p. 271 , p. $1,174 \sim 1,175$, p. 1,344 (1990), 金原出版.

13）厚生省環境衛生局長通知：“麻㾘性貝毒等により毒化した 貝類の取扱いについで昭和 55 年 7 月 1 日, 環乳第 29 号 (1980).

14）（財）日本健康食品協会編：“健康食品規格基準集（その 2)” p. 18 (1987).

15) 日本薬学会編: “衛生試験法注解” p. 424 429 (1990), 金 原出版。

16）石館守三 監修：“食品添加物公定書第四版” p. B-138 B-142 (1979), 廣川書店.

17）福本誠二, 松本俊夫：臨床栄養 74, 571 579 (1989).
*3 長島裕二, 野口玉雄, 橋本周久, 河端俊治：昭和 60 年度日 本水産学会春季大会講演要旨集, p. 205 (1985). 